\title{
Incidence of malaria is clustered and buffers around plantations: a spatial analysis
}

\author{
Yudhi Wibowo*, Agung Saprasetya Dwi Laksana*, Joko Mulyanto*, \\ Madya Ardi Wicaksono*, and Agus Y Purnomo**
}

\begin{abstract}
*Department of Public Health and Community Medicine,

Faculty of Medicine

Jenderal Soedirman University

**Staff at Magetan District Health

Office, Magetan, East Java

\section{Correspondence:}

dr. Yudhi Wibowo, M.Ph

\section{BACKGROUND}

Malaria is re-emerging because of imported cases and the presence of potential vectors that can transmit and spread malaria. Malaria is a health problem in Banyumas District. Mapping the spread of infectious diseases is epidemiologically important. The purpose of this study was to determine the relationship between the variables and the epidemiology of malaria that were spatially modeled using the geographic information system (GIS).
\end{abstract}

Department of Public Health and

Community Medicine,

Faculty of Medicine

Jenderal Soedirman University

Jl. Dr. Gumbreg No. 1, Mersi

East Purwokerto 53112

Phone: +62281-622022

Email: fk@unsoed.ac.id or dryudhiwibowo2005@gmail.com

Univ Med 2015;34:138-48

DOI: 10.18051/UnivMed.2016.v35.138-148 pISSN: 1907-3062 / eISSN: 2407-2230

This open access article is distributed under a Creative Commons Attribution-Non Commercial-Share Alike 4.0 International License

\section{METHODS}

This was a case-control study with ratio of 1:1. Cases were malaria-positive patients and controls were people without malaria, as diagnosed by microscopic examination. Minimum sample size was 139 per group and total sample size was 282 people. Chi-square was used to test the relationship between the variables, and GIS modeling to determine the spatial distribution of malaria cases.

\section{RESULTS}

There were significant relationships between level of income below minimum wage, not using mosquito nets, not using wire netting, not using insect repellents, habit of going out at night, history of malaria, cattle sheds not located between woods and residential area, history of going to endemic areas, residence at distances $\leq 1000 \mathrm{~m}$ from plantations, bushes, swamps and puddles, with incidence of confirmed malaria $(p<0.001)$. The group of cases living $\leq 1000$ meters from plantations numbered $141(100 \%)$.

\section{CONCLUSIONS}

Malaria incidence is clustered and buffers around plantations at $\leq 1000$ $\mathrm{m}$. Malaria hot spots are displayed as risk maps that are useful for monitoring and spatial targeting of prevention and control measures against the disease.

Keywords: Risk factors, spatial analysis, malaria incidence 


\section{Kejadian malaria kluster dan bufer di sekitar perkebunan : model analisis spasial}

\section{ABSTRAK}

\section{LATAR BELAKANG}

Malaria adalah penyakit yang muncul dan muncul kembali karena kasus impor dan potensi vektor yang dapat menularkan dan menyebarkan malaria. Malaria adalah masalah kesehatan di Kabupaten Banyumas. Pemetaan penyebaran penyakit menular secara epidemiologi adalah penting. Tujuan penelitian ini adalah untuk menentukan hubungan antara variabel dan epidemiologi malaria yang dimodelkan secara spasial menggunakan sistem informasi geografis $(S I G)$.

\section{METODE}

Penelitian ini merupakan studi kasus-kontrol dengan perbandingan 1: 1. Kasus adalah semua penderita malaria (+) dan kontrol adalah orang-orang dengan tidak didiagnosis malaria dengan pemeriksaan mikroskopis. Besar sampel minimum 139 per kelompok dan besar sampel total penelitian adalah 282 orang. Chi-square digunakan untuk menguji hubungan antara variabel dan pemodelan menggunakan SIG untuk menentukan distribusi spasial kasus malaria.

\section{HASIL}

Ada hubungan yang bermakna antara tingkat pendapatan kurang upah minimum, tidak menggunakan kelambu, tidak menggunakan kain kawat kasa, tidak menggunakan obat nyamuk, kebiasaan keluar pada malam hari, riwayat penyakit malaria, tata letak kandang ternak tidak di antara hutan dengan perumahan, riwayat bepergian ke daerah endemis, jarak rumah dengan perkebunan, semak-semak, rawa dan genangan air $\leq 1000 \mathrm{~m}$ dengan kejadian konfirmasi malaria (p<0,001). Kelompok kasus yang tinggal $\leq 1000$ meter dari perkebunan adalah 141 (100\%) dari kasus.

\section{KESIMPULAN}

Kejadian malaria adalah kluster dan bufer di sekitar perkebunan yang $\leq 1000 \mathrm{~m}$. Pemetaan malaria ditampilkan sebagai peta risiko yang bermanfaat untuk pemantauan dan penargetan spasial tindakan pencegahan dan pengendalian penyakit.

Kata kunci: Faktor risiko, analisis spasial, kejadian malaria

\section{INTRODUCTION}

Each year Indonesia's 230 million people collectively suffer at least several million cases of malaria caused by all four known species of human Plasmodium. ${ }^{(1)}$ Eastern Indonesia faces the challenges of providing adequate and equitable health services to a largely remote, rural population. Health in the Eastern Indonesian province of Nusa Tenggara Timur (NTT) is generally poor, with high incidence of malaria, high infant mortality rate $(54 / 1000$, compared with 44/1000 nationally), and child malnutrition averaging 39\% and reaching 50\% in some areas. ${ }^{(2)}$ One of the malaria-endemic areas in Indonesia is Central Java Province. The malaria morbidity rate (Anual Parasite Index $=$ API) was $0.1 \%$ in 2011. The number of malaria positive patients in 2010 was 3,300 , increasing to 3,467 people in 2011. In the year 2011 , the case fatality rate for malaria was $0.12 \%$. $^{(3)}$ 
Banyumas is one of the malaria endemic districts in Central Java Province. According to data from the malaria control program at Banyumas District Health Office, an increase in malaria positive patients occurred from 2007 till 2010. In 2010, the highest number of people with malaria was 623 cases. In 2011, 423 of the 1,278 clinical malaria cases were found to be malaria positive. ${ }^{(3)}$ The number of malaria positive patients is the highest in the region, especially at the WatuagungVillage Health Center Tambak I with 146 cases. The second largest number of patients was in the Bogangin and Banjar Penepen Village Health Center Sumpiuh II comprising 117 people. In 2010 an outbreak of malaria occurred in Banyumas, in Ketanda Village (14 malaria positive patients), Sumpyuh sub-district, and in Watuagung Village (30 malaria positive patients), Tambak subdistrict. Based on laboratory tests it is known that the most abundant species is Plasmodium falcifarum.

Several studies have shown that malaria infection is influenced by environmental factors such as temperature, rainfall, humidity, elevation, and factors related to demography. Specifically, temperature and rainfall act as limiting factors on the development of Anopheles mosquitoes which are the intermediate hosts in the transmission of malaria parasites. ${ }^{(4)}$

Transmission dynamics of malaria does not recognize administrative boundaries. The increasing mobility of people from one area to another increases due to advancement and ease of transportation. This increases the risk of malaria transmission due to displacement of the population employed in agriculture, plantations and mining. Individuals working in the forest are at risk of malaria, especially if staying in the forest at night, as found in studies conducted in Central Vietnam by Thanh et al. ${ }^{(5)}$ This is supported by the results of research conducted in Central Vietnam by Thang et al. ${ }^{(6)}$ stating that work in the forest and the home environment are risk factors for the incidence of malaria. Risk factors for malaria in Indonesia, among others, are the geography, gender, education and employment. ${ }^{(7)}$ Mapping the spread of infectious disease is epidemiologically important. Spatial analysis is useful to determine the pattern of distribution of the disease, the high risk areas, the source of disease transmission and disease risk factors in terms of areal, making efforts to control the disease and interrupting the transmission chain, so that the later can be done properly.

The geographic information system (GIS) is a technology to store, manipulate, analyze, and display geographically referenced information. Outside of healthcare, it has been shown to be valuable in a wide range of situations, such as urban planning, environmental resource management, emergency planning, and transportation forecasting. ${ }^{(8)}$ The use of geographic information systems with spatial statistical techniques is useful for measuring the magnitude of the risk of malaria incidence and identify the environmental factors that influence the re-emergence of malaria disease risk factors, so that public health planning should be focused on the maximum spatial cluster region. ${ }^{(9)}$ Control management based on regional spatial data is one of the essential ways to control the disease, especially if backed up by data and epidemiological investigation of outbreaks.

The purpose of this study was to determine the relationship between risk variables and the epidemiology of malaria in Banyumas that is spatially modeled using the GIS.

\section{METHODS}

\section{Research design}

This study was an observational analytic study using case-control design with a ratio of 1: 1 . Research was carried out within 6 months (May to October 2014) and located at the Banyumas, Kemranjen, Sumpyuh and Tambak Health Centers, Banyumas District.

\section{Research subjects}

The population in this study comprised all Banyumas residents who had positive malaria 
by microscopic examination, with the results recorded in the register of Banyumas District Health Office in 2012. The control group were people living in the same district who did not have malaria, as diagnosed by microscopic examination (and recorded in the register of Banyumas District Health Office). Exclusion criteria were positive malaria cases who at the time of the study had died or moved outside the study area.

The sample size was determined based on a 0.05 significance level and power of $80 \%$, with the proportion in the control group being 0.5 and an odds ratio (OR) of 2 obtained, giving a minimum sample size of 139 per group, so that in this study the total sample size was 282 people. ${ }^{(10)}$ The study was conducted in all regions of the sub-districts of Banyumas with cases of malaria, especially Tambak, Sumpyuh, Kemranjen and Banyumas Health Center, because in 2012 the regions had the highest malaria positive case rates in Banyumas. Outbreaks of malaria in 2010 also occurred in this region. All of the malaria positive cases in 2012 were included in the group of cases and controls matched by age and sex.

\section{Data collection}

Data were collected by interview, using a questionnaire comprising items on level of income, use of mosquito nets, wire netting, mosquito repellents, habit of going out at night, history of malarial illness, the location of cattle sheds, a history of travel to endemic areas, distance of residences (settlements) to plantations, bushes, swamps and puddles.

\section{Geographic information system}

The geographic information system is a kind of software that can be utilized for the importation, storage, manipulation, and presentation of geographic information products and their attributes. Geographic information system is software that serves to collect, store, display and connect spatial data about a geographical phenomenon to be analyzed and the results are communicated to the user as a basis for decision making. The coordinates of the respondents' homes were determined using GPS Garmin eTrex 10.

\section{Spatial analysis}

Spatial modeling was performed using computer assistance and mapping software. Buffer analysis of the incidence of malaria in Banyumas in 2012 was used to determine the environmental buffer zone, the suspected breeding sites of the malaria vectors, and the mosquito flying distance to a live subject with positive malaria. The analysis of the environmental buffer zone included rivers, forests, rainfed fields, irrigated fields, plantations, pastures, fields and bushes. Through a spatial query mechanism, a spatial element was taken in the form of a line $1000 \mathrm{~m}$ from the environmental buffer, which then generated new spatial elements such as polygons that cover the environmental buffer. Based on the scope of the polygon, the number of subjects with positive malaria within the scope of the polygon buffer is counted.

Mean center analysis was used to determine the geographic center (central case) of malaria in Banyumas in 2012. From an analysis using GIS software the mean center was obtained. The center was obtained from the mean values of $x$ and $y$ that are calculated to obtain the centroid point of malaria cases in Banyumas. The projection of the point data is used to measure distances accurately. The mean center value of the $\mathrm{x}$ and $\mathrm{y}$ point was derived from the calculation of the mean values of $\mathrm{x}$ and $\mathrm{y}$ and then the $\mathrm{X}$ and $Y$ coordinates were stored. Central points used are the mean centers, and dispersion refers to the spread of the mean centers bounded by polygons. Fields surrounding the polygon centroid were determined based on the distance calculated by using the weighted average of the center of all malaria positive subjects.

Nearest neighbor analysis is an approach to look at the pattern of spread of malaria cases in Banyumas 2012. The calculated Average Nearest Neighbor (ANN) score is used to 
determine the pattern of malaria incidence in Banyumas 2012. ANN can be calculated using the formula: ANN= Ï O / Ï E. ÏO : observed mean distance between each feature and their nearest neighbor, ÏE : expected mean distance for the features given a random pattern.

However, in practice ANN values are calculated using GIS software. ANN values are inferred based on the value of the expected mean distance, and is represented by: (1). ANN = 1 indicating the occurrence of a random pattern, (2). ANN $<1$ indicating the incidence of crowding (clustered), (3). ANN >1 indicating the incident spread (dispersed).

Regarding the incidence of malaria in Banyumas in 2012, there were 140 subjects with positive malaria, therefore $m=140$. Because the area of Banyumas is $1327.60 \mathrm{~km}^{2}$, the value of $\mathrm{A}=1327.60$. The distance between each occurrence is calculated using the Euclidean distance. ANN values are calculated using GIS software.

To determine the presence of a spatial pattern, tests of significance were used: (i). H0: there is no spatial pattern of malaria cases in Banyumas in 2012, Há: there is a spatial pattern of malaria cases in Banyumas in 2012, (ii). Significance level : á, (iii). Critical area H0 is rejected if $\mathrm{Z}$ score $>\mathrm{Z}$ á/2 $=2.58 \mathrm{Z}$ score $<-\mathrm{Z}$ á $/ 2=-2.58$.

The standard deviational ellips (SDE) is used to analyze trends and patterns of dispersion of malaria cases. Standard deviation ellips is a summary of central tendency and dispersion in two dimensions, as well as a directional trend. There are two points that are used as the basis for the distribution of point locations on SDE. They are central tendency and dispersion. Central tendency uses the center of the mean and dispersion refers to the spread of the mean center bounded by the ellipse. Standard deviational ellipse models can be used to gain a better understanding of the geographical aspects of the phenomenon and identify the cause of an event, based on specific geographic patterns. ${ }^{(11)}$

\section{Data analysis}

An odds ratio was used to examine the relationship berween variables, with significant variables being included into a model for multiple logistic regression.

\section{Ethical clearance}

This study was approved by the Commission on Health Research Ethics, Medical School, Jenderal Soedirman University (Unsoed) with Ref no: 100/IEC/VII/2014.

\section{RESULTS}

The analysis using GIS software found a $\mathrm{Z}$ score of -11.17 . Because Z score $=-1117<-$ 2.58 we rejected H0. It can be concluded that there is a spatial pattern of malaria cases in Banyumas in 2012. Because the expected mean distance $=0.44<1$ it can be concluded that the pattern of malaria incidence in Banyumas in 2012 is clustered.

The confirmed participation rate of 141 malaria cases from $214(65.9 \%)$, is sufficient to represent the study and $34.1 \%$ of the confirmed cases was not able to participate in this research because the case had died or moved away with no known address. Most species of mosquitoes captured in the four endemic villages are of the genus Culex spp totalling 106 individuals $(44.7 \%)$ in both indoor and outdoor captures. Species of the genus Anopheles were quite diverse, from the most common type, namely An. vagus (36.3\%), An. barbirostris (7.2\%), An. kochi $(4.6 \%)$, An. maculatus (4.2\%) and An. aconitus (1.3\%). An. aconitus, An. maculatus and An. balabacensis are most commonly found in Watuagung village.

Regarding the characteristics of the respondents, in the group of cases of confirmed malaria, $53.2 \%$ were male, $73.8 \%$ were aged 15 60 years, $54.6 \%$ less educated, $84.4 \%$ income < regional minimum wage (RGW) and $47.5 \%$ were farmers. Results of bivariate analysis showed statistically significant differences $(p<0.001)$ 
Table 1. Relationship between independent variables and incidence of confirmed malaria

\begin{tabular}{|c|c|c|c|c|c|c|}
\hline Variables & & $\begin{array}{c}\begin{array}{c}\text { Cases } \\
(\mathrm{n}=141)\end{array} \\
\mathrm{n}(\%)\end{array}$ & $\begin{array}{c}\text { Controls } \\
(n=141)\end{array}$ & OR & $95 \% \mathrm{CI}$ & $\mathbf{p}^{*}$ \\
\hline Income level & $\begin{array}{l}<\mathrm{RMW} \\
\geq \mathrm{RMW}\end{array}$ & $\begin{array}{c}119(65.1) \\
22(55.6)\end{array}$ & $\begin{array}{l}64(34.9) \\
77(44.4)\end{array}$ & 6.51 & $3.71-11.43$ & $<0.001$ \\
\hline Use of mosquito nets & $\begin{array}{l}\text { Not } \\
\text { Yes }\end{array}$ & $\begin{array}{l}57(90.5) \\
84(38.4)\end{array}$ & $\begin{array}{c}6(9.5) \\
135(61.0)\end{array}$ & 15.27 & $6.31-36.97$ & $<0.001$ \\
\hline Use of wire netting & $\begin{array}{l}\text { Not } \\
\text { Yes }\end{array}$ & $\begin{array}{c}135(38.4) \\
6(11.8)\end{array}$ & $\begin{array}{l}96(41.6) \\
45(88.2)\end{array}$ & 10.55 & $4.33-25.71$ & $<0.001$ \\
\hline Use of mosquito repell ent & $\begin{array}{l}\text { Not } \\
\text { Yes }\end{array}$ & $\begin{array}{l}110(68.8) \\
31(25.4)\end{array}$ & $\begin{array}{l}50(31.2) \\
91(74.6)\end{array}$ & 6.46 & $3.81-10.94$ & $<0.001$ \\
\hline Habit of going out at night & $\begin{array}{l}\text { Yes } \\
\text { Not }\end{array}$ & $\begin{array}{l}59(75.6) \\
82(40.2)\end{array}$ & $\begin{array}{c}19(24.4) \\
122(59.8)\end{array}$ & 4.62 & $2.57-8.32$ & $<0.001$ \\
\hline History of malaria illness & $\begin{array}{l}\text { Yes } \\
\text { Not }\end{array}$ & $\begin{array}{l}91(100.0) \\
50(26.2)\end{array}$ & $\begin{array}{c}0(0.0) \\
141(73.8)\end{array}$ & $* *$ & & \\
\hline Location of cattle sheds & $\begin{array}{l}\text { Not } \\
\text { Yes }\end{array}$ & $\begin{array}{l}97(60.6) \\
44(36.1)\end{array}$ & $\begin{array}{l}63(39.4) \\
78(63.9)\end{array}$ & 2.73 & $1.68-4.44$ & $<0.001$ \\
\hline $\begin{array}{l}\text { History of travel to } \\
\text { endernic areas }\end{array}$ & $\begin{array}{l}\text { Yes } \\
\text { Not }\end{array}$ & $\begin{array}{c}22(88.0) \\
119(46.3)\end{array}$ & $\begin{array}{c}3(12.0) \\
138(53.7)\end{array}$ & 8.50 & $2.48-29.12$ & $<0.001$ \\
\hline Distance from plantations & $\begin{array}{l}\leq 1000 \mathrm{~m} \\
>1000 \mathrm{~m}\end{array}$ & $\begin{array}{c}135(95.1) \\
6(4.3)\end{array}$ & $\begin{array}{c}7(4.9) \\
134(94.7)\end{array}$ & 430.71 & $141.05-1315.21$ & $<0.001$ \\
\hline Distance from bushes & $\begin{array}{l}\leq 1000 \mathrm{~m} \\
>1000 \mathrm{~m}\end{array}$ & $\begin{array}{c}139(77.7) \\
2(1.9)\end{array}$ & $\begin{array}{r}40(22.3) \\
101(98.1)\end{array}$ & 175.49 & $41.45-74295$ & $<0.001$ \\
\hline Distance from swamps & $\begin{array}{l}\leq 1000 \mathrm{~m} \\
>1000 \mathrm{~m}\end{array}$ & $\begin{array}{l}17(100.0) \\
124(46.8)\end{array}$ & $\begin{array}{c}0(0.0) \\
141(53.2)\end{array}$ & $* *$ & & \\
\hline Distance from puddles & $\begin{array}{l}\leq 1000 \mathrm{~m} \\
>1000 \mathrm{~m}\end{array}$ & $\begin{array}{c}106(80.9) \\
35(23.2)\end{array}$ & $\begin{array}{r}25(19.1) \\
116(76.8) \\
\end{array}$ & 14.05 & $7.89-25.02$ & $<0.001$ \\
\hline
\end{tabular}

OR : Odds ratio; $* *$ Cannot be calculated because the cell value $=0$; RMW : regional minimum wage

between the independent variables and the dependent variable (incidence of confirmed malaria) in Banyumas as presented in Table 1. The independent variables were: income < minimum wage, not using mosquito nets, not using wire netting, not using mosquito repellents, habit of going out at night, history of malaria, cattle sheds not located between woods and residential area, history of going to endemic areas, residence at distances $\leq 1000 \mathrm{~m}$ from plantations, bushes, swamps and puddles.

Results of multivariable analysis showed three independent variables that have the highest precision, i.e. location $\leq 1000 \mathrm{~m}$ from puddles, not using mosquito nets and not using insect repellent, and are associated with a statistically significant incidence of confirmed malaria cases as presented in Table 2 .

Table 2. Multivariate logistic regression of selected independent variables with incidence of confirmed malaria

\begin{tabular}{lccc}
\hline \multicolumn{1}{c}{ Variab les } & OR & $\mathbf{9 5 \%}$ CI & P \\
\hline Income < RMW & 15.72 & $2.46-100.48$ & 0.004 \\
N ot using m osquito nets & 6.24 & $1.09-35.56$ & 0.039 \\
H abit of going out at night & 32.05 & $2.84-361.42$ & 0.005 \\
Not usinginsect repellent & 6.65 & $1.18-37.47$ & 0.032 \\
Hist ory of travel to endemic areas & 51.29 & $1.72-1526.50$ & 0.023 \\
Distance from plantation $\leq 1000 \mathrm{~m}$ & 1008.12 & $90.47-11234.31$ & $<0.001$ \\
Distance from puddles $\leq 1000 \mathrm{~m}$ & 6.43 & $1.26-32.74$ & 0.025 \\
\hline
\end{tabular}

RMW : regional minimum wage 

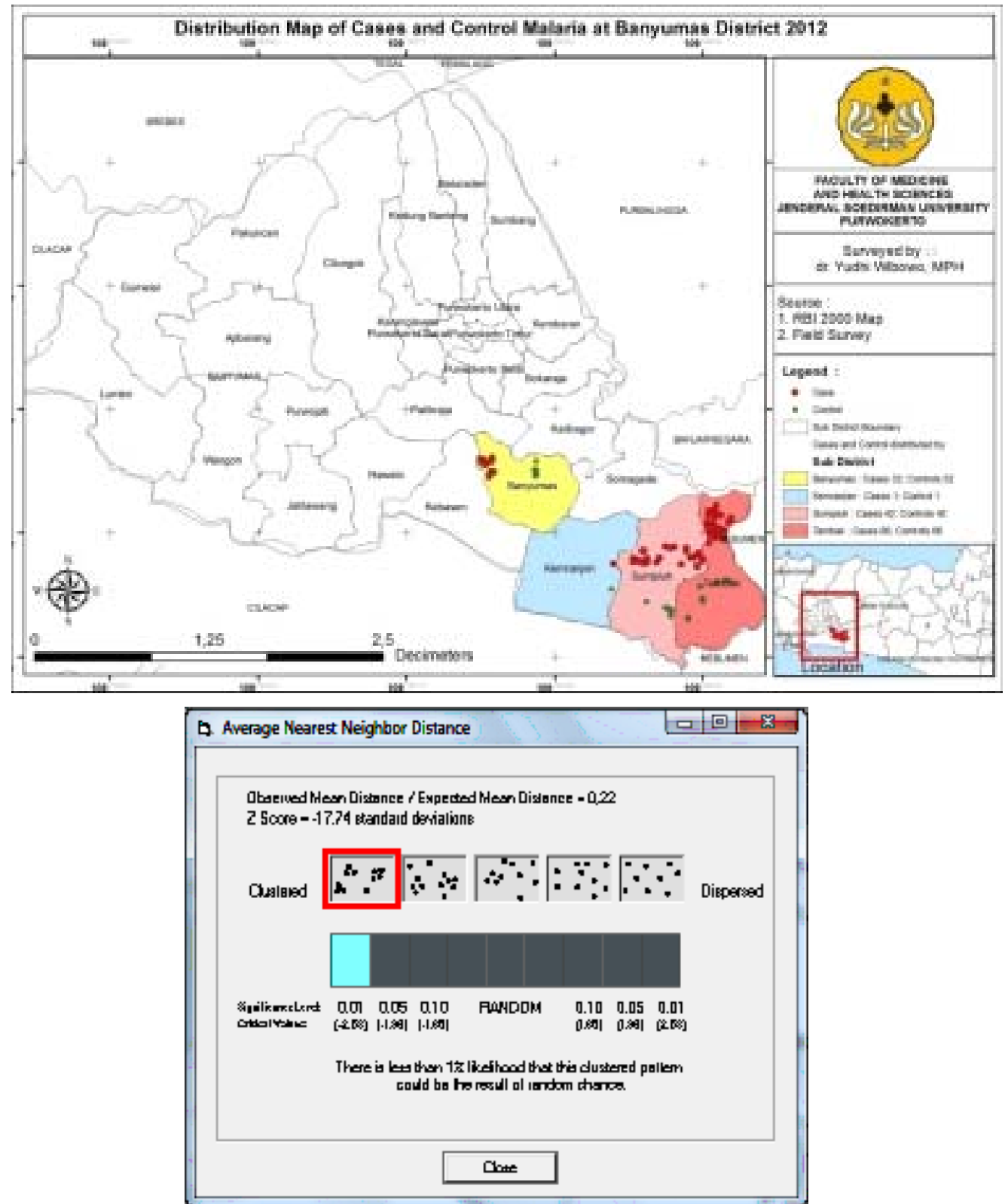

Figure 1. Distribution map of malaria cases and controls in Banyumas District 2012

From the results of the spatial analysis based on the analysis of average nearest neighbor distance, it is known that the distribution of malaria incidence in Banyumas in 2012 was clustered, with $\mathrm{Z}$ score $=-17.74 \mathrm{SD}$ and $\mathrm{p}$-value $<0.001$ as presented in Figure 1.

From the results of the analysis of cases the buffer was found for $141(100 \%)$ of cases to be in the area $\leq 1000$ meters from plantations as presented in Figure 2.

Results of analysis of the SDE in Banyumas showed the axis to be oriented in the Northwest-
Southeast direction. From the corresponding elliptical area on the map can be predicted the possibility of a subsequent spread of malaria upon the presence of risk factors and the absence of supportive intervention services/health workers as shown in Figure 3.

\section{DISCUSSION}

According to Erhart et al. (12) the risk of malaria infection was higher in men than in women because of the influence of gender and 


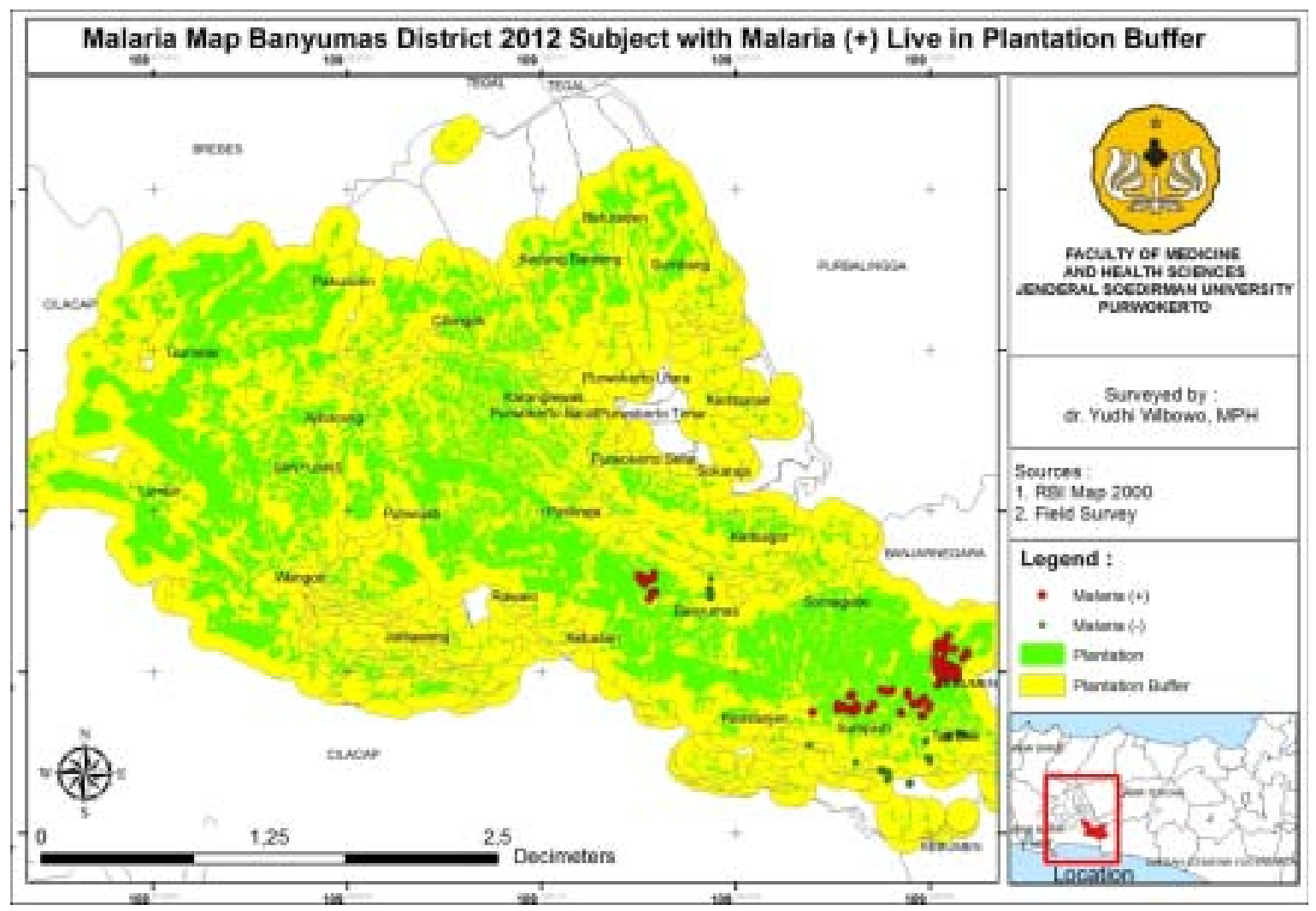

Figure 2. Malaria map of Banyumas District 2012, subjects with positive malaria residing in plantation buffer

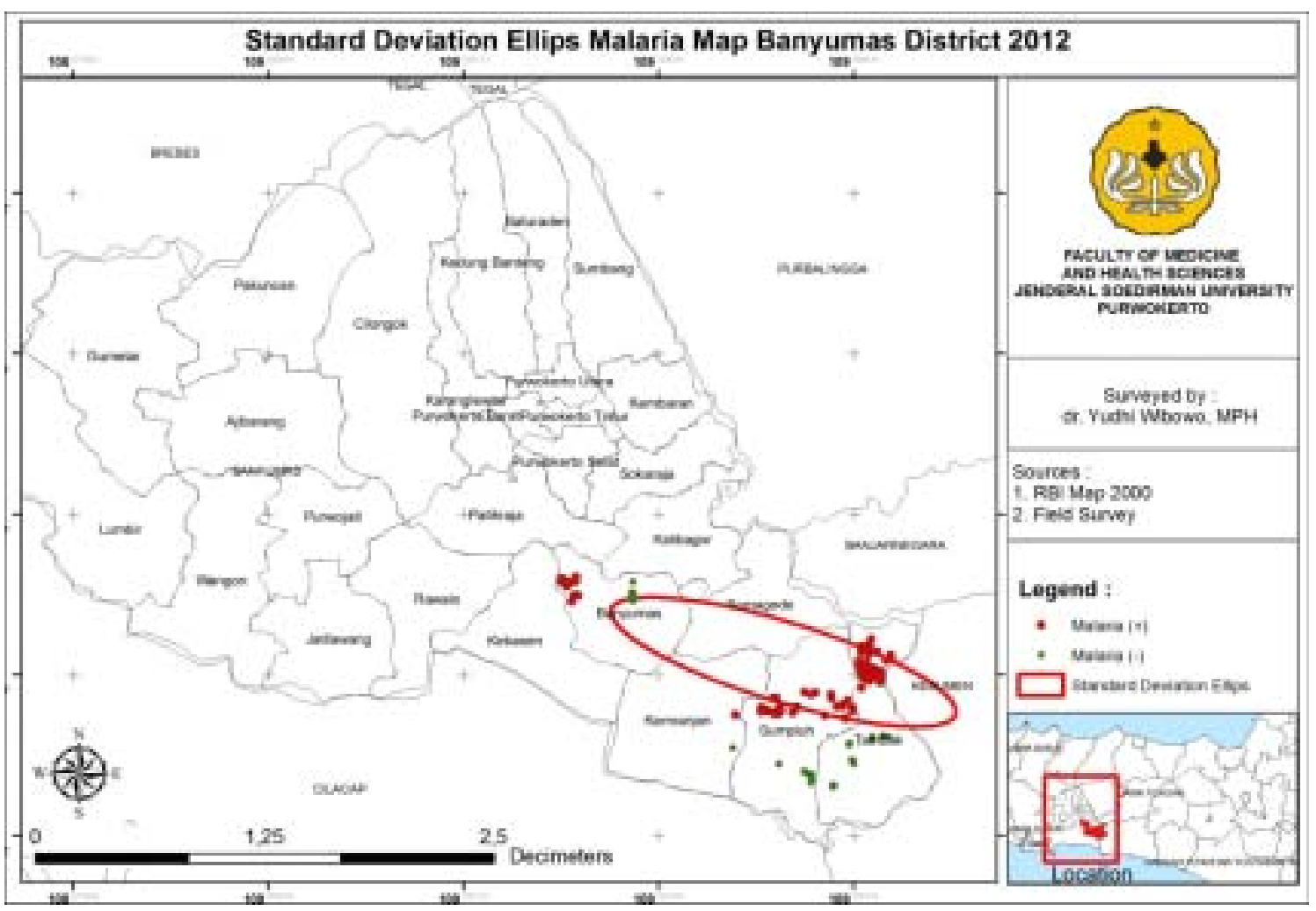

Figure 3. Standard deviational ellipse of malaria map of Banyumas District 2012 
their behavior. In developing countries, an activity that involves the movement of people, including workers in the plantation colonies, increases the risk of malaria transmission. Regarding characteristics of respondents in the cases of confirmed malaria, $47.5 \%$ were clove farmers, rubber farmers, and coconut tree farmers (locally called penderes,i.e. tappers of the sap of coconut inflorescences to be made into brown sugar). The species An. aconitus, An. maculatus and An. balabacensis were most commonly found in Watuagung village. The habitats of An. maculatus are in open hilly areas and mountains where forests have been cleared and is located in the hilly areas of forest. ${ }^{(13)}$ The breeding sites of An. maculatus are puddles that get sunlight, various types of ponds, lakes, marshes, along the banks of slow-flowing streams, ditches and rice fields near the hills. ${ }^{(14)}$ In the confirmed malaria case group, $84.4 \%$ had an income $<$ RMW. According to Dale et al. ${ }^{(15)}$ low income affects fulfillment of living needs, including adequate housing for the residents, health care, and nutritious foods. The malaria risk is increased 2.5 times in people living in houses with shoddy construction (cannot protect occupants from mosquito bites). Not using mosquito nets at night increases the risk of malaria cases and is in accordance with Lozano et al. ${ }^{(16)}$ The use of mosquito nets at night can prevent mosquito bites and to enhance the protection, the recommended type of mosquito nets are nets that have been impregnated with the insecticide permethrin. ${ }^{(17)}$

The use of insecticide-treated nets proved to be able to protect humans from the bite of mosquitoes / malaria vectors. ${ }^{(18,19)}$ Not using wire netting will increase the risk of suffering from malaria 10.55 times and these results are consistent with the research of Kuswanto, ${ }^{(20)}$ who conducted research on malaria risk factors in Banyumas in 2005. Those not using insect repellent are at 6.46-fold increased risk to suffer from malaria. Our study results were in accordance with the results of the study of Kuswanto. ${ }^{(20)}$ Our results shows that the habit of going out at night increases the risk of suffering from malaria 4-5 times. Activities outside the home until late at night in an area with exophilic and exophagic malaria vectors increases the risk of malaria infection. Malaria transmission is highly dependent on the habits of Anopheles mosquitoes and the intensity of malaria transmission is associated with the frequency of a person's activity in areas that allow exposure to the bite of the Anopheles mosquito containing sporozoites. History of travel to endemic areas increases the risk of malaria 8.5 times. Mobility or migration plays a role in moving all ecotypes of malaria, and the spread of new strains with anti-malarial drug resistance, increasing the transmission of malaria from one place to another. Mobility to endemic areas results in an increase in the cases of imported malaria.

The presence of plantations is significantly associated with malaria incidence. Changes in the balance of the forest ecosystem as a result of the clearing of forests for residential land, plantations, and agriculture contributes greatly to increased malaria transmission and epidemics. ${ }^{(21)}$ The presence of shrubs $\leq 1000 \mathrm{~m}$ is statistically significantly associated with the incidence of malaria. During the rainy season the presence of Anopheles habitats not associated with shrubs but positively correlated with the presence of agricultural land, grassland, and shrubs in agricultural areas is a risk factor for malaria incidence. Poor irrigation systems allow the growth of shrubs that could potentially be a breeding ground for Anopheles. Approximately $75.2 \%$ of the cases are in the area $\leq 1000 \mathrm{~m}$ of water pools and statistically significantly associated with the incidence of malaria. The results of the study show that residents who live near stagnant water $(<1000 \mathrm{~m})$ had 2.1 times the risk of malaria infection because stagnant water is where Anopheles sp. multiply. The closer the vector breeding sites are to the residential population, the greater the risk of malaria incidence. ${ }^{(22)}$

The analysis of SDE in Banyumas showed the axis to be oriented in the Northwest-Southeast 
direction. From the corresponding elliptical area on the map, it can be predicted that the possibility of the spread of malaria is in that direction if it is supported by the presence of risk factors and the absence of intervention from the health department. After the implementation of the planned malaria control programs the malaria cases in Banyumas continued to decline from 2012 to 2013 , the number of cases decreasing from 214 to 40 cases.

The results showed that the variables: level of income <RMW, not using mosquito nets, not using wire gauze, not using insect repellent, habit of going out at night, history of malaria illness, cattle sheds not located between plantations and settlements, a history of travel to endemic areas, distance to the plantations, shrubs, swamps and stagnant water $\leq 1000 \mathrm{~m}$, are associated with the incidence of malaria. Results of multivariable analysis showed that level of income <RMW, not using mosquito nets, habit of going out at night, not using insect repellent, history of travel to endemic areas, location of plantations and water pools $\leq 1000 \mathrm{~m}$ from residential buildings, are associated with the incidence of malaria in the malaria districts. The incidence of malaria in Banyumas in 2012 was clustered, with mean and median centers located in the Sumpyuh District. Malaria in the buffer area in Banyumas in 2012 occurred near the plantations with $\leq 1000 \mathrm{~m}$ radius.

Limitations of this study are that biological factors (e.g. existence, type, density and mapping of mosquito vectors) and environmental factors (e.g. temperature, humidity, and weather) that influence the incidence of malaria were not examined in this study. A shortcoming of the analytic-observational study with case-control approach is recall bias, since exposure risk factors have already occurred and to obtain information about these risk factors the investigators must rely solely on the memory of respondents. Selection bias occurs because of the selection of cases based solely on traffic data of patients who went to health services (health centers and hospitals). Controls were selected from surrounding communities among those who did not suffer malaria cases and came from one village, making them less representative of the actual population of controls. Regarding measurement of the coordinates of the respondents using GPS who live around the forest, it is quite difficult to get an accuracy of under 10 meters, so that the investigators had to use a measurement accuracy of under $20 \mathrm{~m}$.

For further research, it is necessary to conduct research related to the causes of malaria (Plasmodium sp.), especially on behavioral aspects, vector bionomics and migration in Banyumas.

\section{CONCLUSIONS}

The incidence of malaria in Banyumas is clustered and buffers around plantations that are located $\leq 1000 \mathrm{~m}$ from residential buildings. Malaria hot spots are displayed as risk maps that are useful for monitoring and spatial targeting of prevention and control measures against the disease.

\section{CONFLICT OF INTEREST}

The authors declare that they have no competing interests.

\section{ACKNOWLEDGEMENT}

Acknowledgements are due to Jenderal Soedirman University, Institute for Research and Community Service, Faculty of Medicine \& Health Sciences, Banyumas District Health Office, and health centers for their cooperation and assistance.

\section{REFERENCES}

1. Elyazar IRF, Hay SI, Baird JK. Malaria distribution, prevalence, drug resistance and control in Indonesia. Adv Parasitol 2011;74: 41175. doi: 10.1016/B978-0-12-385897-9.000021.

2. Fisher RP, Myers BA. Free and simple GIS as appropriate for health mapping in a low resource 
setting: a case study in eastern Indonesia. Int J Health Geogr 2011;10:15. doi: 10.1186/1476072X-10-15.

3. Dinas Kesehatan Kota Banyumas. Laporan hasil kegiatan Program Pengendalian Penyakit Malaria Kabupaten Banyumas Tahun 2013. Purwokerto: Dinas Kesehatan Kota Banyumas; 2013.

4. Kazembe LN, Kleinschmidt I, Holtz TH, et al. Spatial analysis and mapping of malaria risk in Malawi using point-referenced prevalence of infection data. Int J Health Geogr 2006;5:41. doi: 10.1186/1476-072X-5-41.

5. Thanh PV, Hong NV, Van NV, et al. Epidemiology of forest malaria in Central Vietnam: the hidden parasite reservoir. Malar J 2015;14:86. doi: 10.1186/s12936-015-0601-y.

6. Thang ND, Erhart A, Speybroeck N, et al. Malaria in Central Vietnam: analysis of risk factors by multivariate analysis and classification tree models. Malar J 2008;7:28. doi: 10.1186/ 1475-2875-7-28.

7. Ompusunggu S, Tati S, Dewi RM. Faktor risiko malaria di Indonesia (analisis data Riskesdas 2007). Bul Penelit Kesehat 2009; Suppl 11-22.

8. Parmanto B, Paramita MV, Sugiantara W, et al. Spatial and multidimensional visualization of Indonesia's village health statistics. Int J Health Geogr 2008;7:30. doi: 10.1186/1476-072X-7-30.

9. Zhang W, Wang L, Fang L, et al. Spatial analysis of malaria in Anhui Province, China. Malar J 2008;7:206. doi: 10.1186/1475-2875-7-206.

10. Tilaki-Haijan M. Sample size estimation in epidemiologic studies. Caspian J Intern Med 2011;2:289-98

11. Eryando T, Susanna D, Pratiwi D, et al. Standard deviational ellipse (SDE) models for malaria surveillance, case study: Sukabumi districtIndonesia, in 2012. Malar J 2012; 11 Suppl 1: 130. doi: 10.1186/1475-2875-11-S1-P130.

12. Erhart A, Ngo DT, Phan VK, et al. Epidemiology of forest malaria in central Vietnam: a large scale cross-sectional survey. Malar J 2005;4:58.
13. Ndoen E, Wild C, Dale P, et al. Relationships between Anopheline mosquitoes and topography in west Timor and Java, Indonesia. Malar J 2010; 9:242. doi: 10.1186/1475-2875-9-242.

14. Sinka ME, Bangs MJ, Manguin S, et al. The dominant Anopheles vectors of human malaria in the Asia-Pacific Region: occurrence data, distribution maps and bionomic précis. Parasit Vectors 2011;4:89.

15. Dale P, Sipe N, Anto S, et al. Malaria in Indonesia: a summary of recent into its environmental relationship. Southest Asian J Trop Med Public Health 2005;36:1-13.

16. Lozano DR, Rodriguez MH, Betnzos-Reyes AF, et al. Individual risk factors for Plasmodium vivax infection in the residual malaria transmission focus of Oaxaca, Mexico. Salud Publica de Mexico 2007;49:199-209.

17. Badan Penelitian dan Pengembangan Departemen Kesehatan RI. Laporan nasional riset kesehatan dasar tahun 2010. Jakarta: Badan Penelitian dan Pengembangan Departemen Kesehatan RI;2010.

18. Winskill P, Rowland M, Mtove G, et al. Malaria risk factors in north-east Tanzania. Malar J 2011; 10:98. doi: 10.1186/1475-2875-10-98.

19. Alemu A, Tsegaye W, Golassa L, et al. Urban malaria and associated risk factors in Jimma town, south-west Ethiopia. Malar J 2011;10:173.

20. Kuswanto. Analisis faktor-faktor risiko kejadian malaria di kecamatan Kemranjen Kabupaten Banyumas [tesis]. Semarang: Program Pascasarjana Universitas Diponegoro;2005.

21. Mushinzimana E, Munga S, Minakawa N, et al. Landscape determinants and remote sensing of Anopheline mosquito larval habitats in the western Kenya highlands. Malar J 2006;5:13.

22. Kazwaini M, Martini S. Tempat perindukan vektor, spesies nyamuk Anopheles, dan pengaruh jarak tempat perindukan vektor nyamuk Anopheles terhadap kejadian malaria pada balita. J Kesehatan Lingkungan 2006;2:173-82. 